УДК 338.486

А. В. Батуров [A. V. Baturov]

В. Ф. Кшишневская [V. F. Kshishnevskaya]

\title{
СОВЕРШЕНСТВОВАНИЕ МЕТОДОВ ОЦЕНКИ УСТОЙЧИВОСТИ ПРЕДПРИЯТИЙ ТУРИСТИЧЕСКОЙ ИНДУСТРИИ НА РЕГИОНАЛЬНОМ УРОВНЕ
}

\section{IMPROVEMENT OF METHODS FOR ASSESSING THE FINANCIAL STABILITY OF TOURISM INDUSTRY ENTERPRISES AT THE REGIONAL LEVEL}

\author{
Институт сервиса, туризма и дизайна (филиал) СКФУ в г. Пятигорске, Россия
} Institute of Service, Tourism and Design (branch) NCFU in Pyatigorsk, Russia

\begin{abstract}
Аннотация. Статья посвяцена применению методов стресс-тестирования для оценки риска возможного банкротства для туристических колпаний на уровне региона. При сиенариях изленения турпотока от 100\% до $50 \%$ и $30 \%$, динамика корреляиий исследуемых показателей показьвает не критичнуо диналику ослабленил тесноть связи. Стресстест показал некоторый запас прочности санаторно-курортного колплекса региона Кавказских Минеральных Вод.
\end{abstract}

Ключевые слова: туризм, рекреационный потенциал, риск-менеджмент, конкурентные преимуцества, туристические услуги.

Abstract. The article is devoted to the application of stress testing methods to assess the risk of possible bankruptcy of tourist companies at the regional level. In the scenarios of changes in the tourist flow from $100 \%$ to $50 \%$ and $30 \%$, the dynamics of correlations of the studied indicators shows a non-critical dynamics of weakening the tightness of the connection. There are probably hidden nonlinear dependencies of the studied indicators. The stress test showed a certain margin of safety of the health resort complex of the Caucasus Mineral Waters region.

Key words: tourism, recreation potential, risk-management, competitive advantages, travel services.

Introduction. Risk is an integral part of a person and society life. At the organizational level, economic risk is more significant, it regulates the microeconomic relations of companies when making management decisions. In this case, it is necessary to take into account the resulting influence of external and internal factors, which in turn are subject to constant qualitative and quantitative changes [4].

A potential hazard can be viewed as an uncertain event or condition that, when realized, has a positive or negative impact on the company's reputation, leads to monetary gains or losses [12].

The concept of "force majeure" is defined in accordance with paragraph 3 of Article 401 of the Civil Code of the Russian Federation. In particular, force majeure circumstances include: natural disasters (earthquake, flood, hurricane), fire, epidemics, strikes, hostilities, terrorist acts, sabotage, restrictions on traffic, prohibitive measures of states, prohibition of trade operations, including with certain countries due to the adoption of international sanctions, and other circumstances beyond the control of the parties to the agreement (contract). The epidemic of coronavirus can be attributed to force majeure circumstances, but the lack of clarity and confusion of domestic legislation does not allow this to be done unambiguously.

Today, the Russian economy is facing the most serious crisis in the past two decades. This crisis was caused by extreme measures to combat the pandemic and changes in commodity markets, leading to a significant drop in the income of the Russian economy. Measures of the governments of all countries to combat the pandemic are mandatory for society and lead to a sharp contraction in demand, a reduction in the activity of the service sector (passenger transportation, tourism, hotel, restaurant, recreational businesses). Support programs include: fiscal measures (reducing the actual tax burden), replacing shortfalls in budget revenues, maintaining the availability of lending to businesses and the population, budget support for companies and the population in order to maintain employment and effective demand. These measures will prevent the transition of the recession into depression and ensure its $\mathrm{V}$-shaped development [6] .

As of early April of this year, the World Tourism Organization (UNWTO) predicted a 20-30\% decrease in tourist activity in 2020, as a result of which the world economy will receive less from $\$ 30$ billion to $\$ 50$ billion (from 2.2 to 3.7 trillion rubles). According to UNWTO forecasts, the decrease in the number of tourists will continue in the coming years. Lost profits of the global aviation industry in 2020 compared to last year will amount to $38 \%$, or $\$ 252$ billion (1.9 thousand trillion rubles). Sales in the field of tourism in Russia fell to almost minimal values, according to the results of the first half of the year, the total volume of lost revenue by the Russian tourism business will be about 1.5 trillion rubles. According to estimates, there are 1,800 sanatorium-resort institutions in Russia in total, of which 700 are state-owned, the rest are private. The sharp decline in tourism industry revenues increased the risks of non-payment of wages to employees, rent and utility payments, taxes and loan repayment. More than 1.6 million people were under threat of dismissal or sending on unpaid leave. The total number of workers in the tourism industry is 2.5 million, taking into account related industries about 7 million people [11]. 
The onset of risk in the economic activity of a tourism organization leads to the disruption of plans, in the form of unplanned expenses, losses or a decrease in expected income [5,12]. Risk classification should be understood as the distribution of risk into specific groups according to certain criteria to achieve the set goals [9]:

- operational (violation of the internal business processes of the organization;

- environmental, (external threat of environmental degradation);

-A security risk (the threat of reducing the attractiveness of a tourist destination from a safety point of view);

- political (threat of deterioration of the political situation);

- marketing (threat of an unfavorable situation in the markets);

- economic (threat of deterioration of the economic situation);

- infrastructural, (decrease in the quality of tourism infrastructure).

There are also two main categories of risks in tourism:

1) risks that directly threaten tourists when planning and implementing a tour (tourist risks);

2) the risks of the activities of tourism enterprises from the provision of services to tourists, during the formation and promotion of the tour (economic and economic risks) [8] .

The tourism industry can have a multiplier effect on the development of other sectors of the region's national economy (agriculture, transport, construction, trade, services, etc.) and can ensure sustainable growth of the regional economy. However, it is associated with the risks of the industries entering the tourism industry, which also enhance or compress the multiplier effect, adding to the overall level of tourism risk.

The variety of tourist resources of the North Caucasus Federal District contributes to the development of various types of inbound and domestic tourism: recreational, cultural, educational, extreme, ski, business, ecological, rural, fishing and hunting.

The Government of the Russian Federation pays significant attention to the development of the region: the state program "Development of the North Caucasian Federal District for the period up to 2025 (the volume of budget allocations is 305 billion rubles)" and a number of subprograms ("Development of the tourist cluster in the North Caucasian Federal District") have been adopted.

Tasks of these subprograms: creation of conditions for attracting investments; infrastructure development; creation and promotion of local tourism products in the domestic and foreign markets; a significant increase in the tourist flow; development of industry and agriculture on the territory of the federal district. JSC "Resorts of the North Caucasus" assessed the tourist and recreational potential of the North Caucasus Federal District. The region was supposed to develop all-season tourist and recreational complexes in the following territories: (Karachay-Cherkess Republic "Arkhyz"), (Kabardino-Balkarian Republic "Elbrus") (Chechen Republic "Veduchi"), (Republic of Ingushetia "Tsori", "Armkhi »), (Republic of Dagestan - Caspian coastal cluster) [10].

It was planned that by 2025 :

-12.8 thousand jobs would be created,

- the proceeds from the sale of goods and services would reach 19.5 billion rubles.

Over the past five years, more than 2 trillion rubles have been allocated to solve social and economic problems in the region. In 2019, the subjects of the North Caucasus Federal District received 70 billion from the budget for the implementation of national projects, and 200 billion rubles for state programs. However, not all targets were met. At the same time, the values of socio-economic indicators there still lag behind the national average. Unemployment is $11 \%$, and in the country $-4.6 \%$. The average monthly salary is $61 \%$ of the national average [10].

In 2019, the resorts of the republics of the North Caucasus Federal District were visited by about 4 million people, the Stavropol Territory - about 1.6 million people. The ski tourism cluster will be able to accommodate up to 100 thousand vacationers at a time. Paid travel services amounted to more than 6 billion rubles, sanatorium and health services more than 3 billion rubles.

As a result of anti-epidemic measures, the regional tourism and hospitality industry (hotel business, catering enterprises, transport, cultural and entertainment services) will be seriously affected. The introduction of a self-isolation regime for Russian regions in order to reduce the spread of coronavirus in the short term will seriously affect the financial condition of the health resorts of the Caucasian Mineral Waters region, the hotel business of the all-season resorts Arkhyz, Elbrus, Veduchi and others. According to the press service of the Ministry of Tourism of the Stavropol Territory, tourist flow in the region in March 2020 fell by 34\% against last year. Sanatoriums are loaded by $65 \%$, in hotels there are fewer guests by $28 \%$. By the Decree of the Governor of the Stavropol Territory dated 04/31/2020. No. 123, the reception and placement of citizens in collective accommodation facilities from April 31 to June 01, 2020 was restricted.

The purpose of our research is to qualitatively analyze the risks of the impact of economic, infrastructural, market factors on the local market of tourist and recreational services in the North Caucasus Federal District.

When analyzing risks, a qualitative analysis is carried out in order to identify risks, which includes the following tasks: identifying risks; classification and description of risks, analysis. Quantitative analysis aims at determining the size of the risk, calculating risks and assessing them.

In world practice, these methods of analysis are used to obtain the most effective analysis of risks $[1,7]$ :

- method of reliable equivalents (reliability factors)

- method of adjusting the discount rate; 
- sensitivity analysis of indicators (univariate stress test);

- scenario method (multivariate stress test);

- analysis of probable distributions;

- Monte Carlo method (simulated distribution).

Sensitivity analysis of indicators is widely used in the practice of financial management. In the general case, it boils down to the study of the dependence of a certain resulting indicator on the variation in the values of indicators involved in its determination. (analysis of "what if"). The problem is that in stressful situations, other risk factors change, if only one is considered, the measurements may be inaccurate. Hypothetical scenarios may consider worst-case outcomes when the considered risk factors have worst-case values. This method does not account for correlations between other risk factors. There are points of view on how the correlations between risk factors should change [1]:

- in stressful situations, the relationships between factors remain the same as in the norm;

- in stressful situations, the relationships between the factors change.

In the previous study, we carried out a cluster analysis of the distribution of tourist and recreational resources within the North Caucasus Federal District, which made it possible to differentiate the distribution of these resources by the subjects of the region. Critical indicators for assessing the sensitivity (competitiveness) of the region's tourism industry to changes in external factors (changes in tourist traffic) have been identified [2.3].

Methodology. The competitiveness of a territory is the basis for its stability in the case of adverse events. To accomplish this task, it is necessary to identify indicators characterizing the development of the tourist and recreational complex in the region. The indicators of regional development of the industry were calculated on the basis of primary indicators.

The sources of information are official statistical data, as well as mass media, scientific publications, sociological surveys (questionnaires, interviews), methods of expert assessments ("focus groups") and others.

Indicators can be presented in nominal or structural indexes, using content analysis, as well as comparison and grouping methods.

We have grouped the indicators into blocks that were used to determine the competitiveness of the regional tourism market and can be applied as scenario criteria [3]:

1. Socio-economic situation;

2. Business conditions;

3. Environment;

5. Infrastructure and economy of the tourism industry.

We settled on a scenario where several risk factors are subjected to stress testing, while the rest can change only in accordance with their historical values. The scenario assumes measuring the sensitivity of the regional tourism market indicators depending on changes in tourist traffic: 100\% (column 1), 50\% (column 2), 30\% (column 3). Tourist flow of 30\% from 2019 approximately coincides with the health resort contingent. Other indicators were also adjusted: passenger transportation, collective accommodation facilities, sanatoriums, places and number of people. The number of scenario parameters can be minimized using correlation analysis.

Pearson's correlation coefficient indicates that either one of the two identified phenomena is a partial cause of the other, or both phenomena are a consequence of common causes. The correlation coefficient can range from -1 to +1 . At the same time, a negative correlation coefficient indicates that an increase in the value of one variable corresponds to a decrease in the value of another variable correlating with it. A positive correlation coefficient indicates that an increase in one variable corresponds to an increase in another. The main hypothesis is that there is no linear feedback between variables. At $p<0.05$, the hypothesis is rejected. Correlation strength classification: strong: \pm 0.7 to \pm 1 ; average: \pm 0.3 to \pm 0.699 ; weak: 0 to \pm 0.299 .

Table 1

Indicators of the block " Socio-economic situation "

\begin{tabular}{|c|c|c|c|c|c|c|c|c|c|c|c|c|c|c|c|}
\hline \multirow[t]{2}{*}{ Indicators } & \multicolumn{3}{|c|}{$\begin{array}{c}\text { Average } \\
\text { per capita income } \\
\text { population per month, } \\
\text { rub }\end{array}$} & \multicolumn{3}{|c|}{$\begin{array}{c}\text { Level of } \\
\text { unemployment, } \%\end{array}$} & \multicolumn{3}{|c|}{ Number of doctors } & \multicolumn{3}{|c|}{$\begin{array}{c}\text { Number of hospital } \\
\text { beds }\end{array}$} & \multicolumn{3}{|c|}{$\begin{array}{l}\text { Number of } \\
\text { crimes }\end{array}$} \\
\hline & 1 & 2 & 3 & 1 & 2 & 3 & 1 & 2 & 3 & 1 & 2 & 3 & 1 & 2 & 3 \\
\hline $\begin{array}{c}\text { Amount } \\
\text { of tourists }\end{array}$ & 0,22 & 0,23 & 0,22 & $-0,59$ & $-0,58$ & $-0,58$ & 0,23 & 0,17 & 0,16 & 0,81 & 0,92 & 0,9 & 0,86 & 0,77 & 0,75 \\
\hline
\end{tabular}

Indicator "Average per capita income of the population per month, rubles." Table 1 has a weak positive correlation with the number of tourists +0.22 , which reflects the irregular development of the subjects of the region and the presence of other incomes not related to the tourism industry. Despite the insignificant share of the tourism industry in the sectoral gross value added of about 3\% in the federal district, the tourist flow has an average positive feedback with the indicator "GRP( Gross regional product) per capita" 0.67-0.65.

The "Level of unemployment" indicator has an average negative correlation with the number of tourists - 0.590.58. The decrease in tourist flow contributes to the growth of unemployment. The indicator "The number of doctors" has a weakly expressed positive feedback with the number of tourists +0.23 to 0.16 . This can be explained by the fact that not a large part of tourists go to continue their treatment, focusing on the sanatorium-resort complex. Therefore, the 
indicator "Number of hospital beds" has a strong positive correlation +0.9 to 0.81 . In case of exacerbation of chronic diseases and injuries, hospitalization of tourists is carried out by local health care institutions. The indicator "Number of crimes" has a strong feedback $+0.86+0.77$ with the number of tourists who themselves may commit crimes and be subject to criminal acts.

Table 2

Indicators of the "Business conditions"

\begin{tabular}{|c|c|c|c|c|c|c|c|c|c|c|c|c|c|}
\hline \multirow{2}{*}{ Indicators } & \multicolumn{4}{|c|}{ GRP per capita, rubles } & \multicolumn{3}{c|}{$\begin{array}{c}\text { Fixed capital investments } \\
\text { per capita, rubles }\end{array}$} & \multicolumn{2}{c|}{$\begin{array}{c}\text { Share of the tourism in- } \\
\text { dustry in the sectoral gross } \\
\text { value added\% }\end{array}$} & \multicolumn{3}{c|}{$\begin{array}{c}\text { Share of investments in } \\
\text { fixed assets from the } \\
\text { budget\% }\end{array}$} \\
\cline { 2 - 14 } & 1 & 2 & 3 & 1 & 2 & 3 & 1 & 2 & 3 & 1 & 2 & 3 \\
\hline Amount of tourists & 0,67 & 0,67 & 0,65 & 0,27 & 0,31 & 0,31 & 0,08 & 0,16 & 0,18 & $-0,75$ & $-0,72$ & $-0,72$ \\
\hline
\end{tabular}

The indicator "Fixed capital investments per capita, rubles" has an average correlation with the indicator under study. Table 2. The indicator of tourist flow has a strong negative feedback to indicator "Share of investments in fixed assets from the budget", which characterizes the significant role of the state in the development of infrastructure (-0, 750.72). The indicator "Share of the tourism industry in the sectoral gross value added" has a weakly expressed positive feedback with tourist flow.

Table 3

Indicators of the block "Environment"

\begin{tabular}{|c|c|c|c|c|c|c|c|c|c|c|c|c|c|c|c|}
\hline \multirow[t]{2}{*}{ Indicators } & \multicolumn{3}{|c|}{$\begin{array}{l}\text { Atmospheric emis- } \\
\text { sions from stationary } \\
\text { sources, thousand } \\
\text { tons }\end{array}$} & \multicolumn{3}{|c|}{$\begin{array}{l}\text { Atmospheric emis- } \\
\text { sions from mobile } \\
\text { sources, thousand } \\
\text { tons }\end{array}$} & \multicolumn{3}{|c|}{$\begin{array}{l}\text { Discharge of waste } \\
\text { water into surface } \\
\text { water bodies, mln.m3 }\end{array}$} & \multicolumn{3}{|c|}{$\begin{array}{l}\text { Production and con- } \\
\text { sumption waste, } \\
\text { thousand tons }\end{array}$} & \multicolumn{3}{|c|}{ Population density } \\
\hline & 1 & 2 & 3 & 1 & 2 & 3 & 1 & 2 & 3 & 1 & 2 & 3 & 1 & 2 & 3 \\
\hline Amount of tourists & 0,71 & 0,7 & 0,7 & 0,71 & 0,58 & 0,58 & 0,75 & 0,68 & 0,68 & 0,84 & 0,75 & 0,75 & $-0,78$ & $-0,87$ & $-0,87$ \\
\hline
\end{tabular}

Table 3 shows a strong positive feedback between the main indicators of anthropogenic load and tourist flow, the more tourists, the more pollution:

- "Atmospheric emissions from stationary sources" $(+0.71+0.7)$

- " Discharge of waste water into surface water bodies" $(+0.75+0.68)$,

- "Production and consumption waste" $(+0.84+0.75)$.

- "Atmospheric emissions from mobile sources" $(0.71+0.58)$. A decrease in tourist flow has a slight effect on environmental pollution. The tourist flow has the opposite effect on the "Population density" (-0.78-0.87): in one place the population density temporarily increases, while in another it decreases.

Table 4

Indicators of the block "Infrastructure and economy of the tourism industry"

\begin{tabular}{|c|c|c|c|c|c|c|c|c|c|c|c|c|c|c|c|}
\hline \multirow[t]{2}{*}{ Indicators } & \multicolumn{3}{|c|}{$\begin{array}{l}\text { Rail transportation, } \\
\text { thous. } \\
\text { passengers }\end{array}$} & \multicolumn{3}{|c|}{$\begin{array}{c}\text { Automobile } \\
\text { (buses) transporta- } \\
\text { tion, } \\
\text { thous. } \\
\text { passengers }\end{array}$} & \multicolumn{3}{|c|}{$\begin{array}{l}\text { Air transportation, } \\
\text { thous. } \\
\text { passengers }\end{array}$} & \multicolumn{3}{|c|}{$\begin{array}{l}\text { Collective } \\
\text { facilities } \\
\text { placement, } \\
\text { places }\end{array}$} & \multicolumn{3}{|c|}{$\begin{array}{c}\text { Collective } \\
\text { facilities } \\
\text { accommodation, } \\
\text { thous. people }\end{array}$} \\
\hline & 1 & 2 & 3 & 1 & 2 & 3 & 1 & 2 & 3 & 1 & 2 & 3 & 1 & 2 & 3 \\
\hline Amount of tourists & 0,86 & 0,73 & 0,72 & 0,79 & 0,68 & 0,67 & 0,78 & 0,67 & 0,67 & 0,92 & 0,73 & 0,72 & 0,95 & 0,8 & 0,79 \\
\hline
\end{tabular}

In table 4, the indicators "Infrastructure and economy of the tourism industry" show a positive feedback with tourist flow. Developed transport infrastructure ("Railroad transportation" $(+0.86+0.72)$, "Automobile transportation" $(+0.79+0.67)$, "Air transportation" $(+0.78+0.67)$, has a positive effect on the number of tourists. The first place in transportation is traditionally kept by railway transport, the second place - by road transport and the third place - by aviation. Road transport and aviation have a tendency to decrease to an average positive correlation. Local residents and residents of neighboring regions arrive in road transport.

Table 4.1

Indicators of the block "Infrastructure and economy of the tourism industry"

\begin{tabular}{|c|c|c|c|c|c|c|c|c|c|c|c|c|c|c|c|c|c|c|}
\hline \multirow[t]{2}{*}{ Indicators } & \multicolumn{3}{|c|}{$\begin{array}{l}\text { Health resort } \\
\text { facilities, places }\end{array}$} & \multicolumn{3}{|c|}{$\begin{array}{c}\text { Health resort } \\
\text { facilities, accom- } \\
\text { modated thous. } \\
\text { people }\end{array}$} & \multicolumn{3}{|c|}{$\begin{array}{l}\text { Paid travel ser- } \\
\text { vices, thous. ru- } \\
\text { bles }\end{array}$} & \multicolumn{3}{|c|}{$\begin{array}{l}\text { Health resort } \\
\text { services, thous. } \\
\text { rubles }\end{array}$} & \multicolumn{3}{|c|}{$\begin{array}{l}\text { Services of collec- } \\
\text { tive accommoda- } \\
\text { tion facilities, } \\
\text { thous. rubles }\end{array}$} & \multicolumn{3}{|c|}{$\begin{array}{l}\text { Number of peo- } \\
\text { ple, employed in } \\
\text { the tourism indus- } \\
\text { try }\end{array}$} \\
\hline & 1 & 2 & 3 & 1 & 2 & 3 & 1 & 2 & 3 & 1 & 2 & 3 & 1 & 2 & 3 & 1 & 2 & 3 \\
\hline Amount of tourists & 0,86 & 0,77 & 0,75 & 0,86 & 0,73 & 0,7 & 0,4 & 0,49 & 0,5 & 0,86 & 0,74 & 0,71 & 0,85 & 0,7 & 0,66 & 0,65 & 0,6 & 0,57 \\
\hline
\end{tabular}


The next significant group of indicators in Tables 4 and 4.1 characterizes collective accommodation facilities: hotels, camp sites, campgrounds, rest houses, boarding houses and, separately, sanatoriums. This group also shows a strong positive feedback with the number of tourists:

- "Collective accommodation facilities, places" $(+0.92+0.72)$,

- "Collective accommodation facilities, thousands of people accommodated" $(+0.95+79)$,

- "Health resort facilities " $(+0.86+0.75)$,

- "Health resort facilities, thousands of people accommodated" $(+0.86+0.7)$,

According to the indicators "Collective accommodation facilities, beds", "Collective accommodation facilities, thousands of people accommodated", the differences in the correlation coefficients can be explained by uneven loading of the bed fund. The downward trend in communication density can be traced as the tourist flow changes.

According to the indicators "Health resort institutions, beds", "Health resort institutions, accommodated thousands of people", the difference in the correlation coefficients is explained by the lower load of the bed fund.

The third group of indicators characterizes the volume of paid services and employment in the region's tourism industry. In this group, there is also a positive feedback with the number of tourists:

- "Paid travel services" $(+0.4+0.5)$,

- "Health resort services" $(+0.86+0.71)$,

- "Services of collective accommodation facilities" $(+0.85+0.66)$,

— "Number of people employed in the tourism industry" $(+0.65+0.57)$.

The growth of the "Paid tourist services" indicator with an average correlation coefficient of up to $0.5+0.4$ reflects the fact that vacationers will attend excursions and entertainment events.

The downward trend in the positive feedback of the indicators "Health resort services" from +0.86 to +0.71 and "Services of collective accommodation facilities" from +0.85 to average +0.66 with a change in tourist flow is characterized by a lower volume of spa and cosmetic procedures, therapeutic massage.

A decrease in the correlation of the indicator "Number of employed in the tourism industry" from +0.65 to an average of +0.57 is also characterized by a positive feedback with tourist flow and reflects a decrease in employment and the seasonality of the provision of travel services.

Table 5

Influence of the "Business conditions" indicators on the indicators of the "Infrastructure and economy of the tourism industry"

\begin{tabular}{|c|c|c|c|c|c|c|c|c|c|}
\hline \multirow[t]{2}{*}{ Indicators } & \multicolumn{3}{|c|}{ GRP per capita, rubles } & \multicolumn{3}{|c|}{$\begin{array}{l}\text { Fixed capital investments } \\
\text { per capita, rubles }\end{array}$} & \multicolumn{3}{|c|}{$\begin{array}{c}\text { Share of investments in } \\
\text { fixed assets at the expense } \\
\text { of the budget }\end{array}$} \\
\hline & 1 & 2 & 3 & 1 & 2 & 3 & 1 & 2 & 3 \\
\hline Collective accommodation facilities, places & 0,63 & 0,56 & 0,54 & 0,17 & 0,17 & 0,13 & $-0,74$ & $-0,67$ & $-0,63$ \\
\hline $\begin{array}{l}\text { Collective accommodation facilities, thousands of } \\
\text { people accommodated }\end{array}$ & 0,6 & 0,6 & 0,6 & 0,2 & 0,2 & 0,2 & $-0,74$ & $-0,71$ & $-0,68$ \\
\hline Health resort facilities, places & 0,56 & 0,6 & 0,61 & 0,06 & 0,2 & 0,2 & $-0,68$ & $-0,67$ & $-0,67$ \\
\hline Health resort facilities, accommodated thous. people & 0,54 & 0,54 & 0,54 & 0,06 & 0,1 & 0,1 & $-0,68$ & $-0,67$ & $-0,65$ \\
\hline Health resort services, thous. rubles & 0,54 & 0,54 & 0,54 & 0,13 & 0,12 & 0,1 & $-0,66$ & $-0,66$ & $-0,66$ \\
\hline $\begin{array}{l}\text { Services of collective accommodation facilities, } \\
\text { thous. rubles }\end{array}$ & 0,65 & 0,63 & 0,6 & 0,58 & 0,82 & 0,84 & $-0,77$ & $-0,58$ & $-0,55$ \\
\hline $\begin{array}{l}\text { Number of employees in the tourism industry, thous. } \\
\text { people }\end{array}$ & 0,8 & 0,8 & 0,8 & 0,79 & 0,79 & 0,79 & $-0,26$ & $-0,41$ & $-0,45$ \\
\hline
\end{tabular}

Our research has revealed a medium and strong feedback between "GRP per capita" and indicators of the section "Infrastructure and economy of the tourism industry". In Table 5, the indicator " Number of employees in the tourism industry " showed a strong positive feedback with the indicator "GRP per capita" +0.8 , which will directly affect employment in the region as a whole.

The indicators of the block "Infrastructure and economy of the tourism industry" has a weak dependence on the indicator "Fixed capital investments per capita", with the exception of "Services of collective accommodation facilities" and "Number of employees in the tourism industry" which showed a strong positive feedback of 0.8 . The indicator "Share of investments in fixed assets at the expense of the budget" did not have an average negative impact on the indicators of the section "Infrastructure and economy of the tourism industry". This situation is explained by the fact that most of the collective accommodation facilities and sanatoriums were built during the Soviet era and additional private investments in the 2000s did not have a significant impact on the industry. The regional tourism infrastructure still depends on public investment.

In our previous study, we carried out a cluster analysis of the subjects of the North Caucasus Federal District from the point of view of the tourism industry infrastructure using the "Ward's" method: the distance between objects was measured using the "City-Block" method. First, in both clusters, for all available observations, the average values of individual variables are calculated. Then, the squared Euclidean distances from individual observations of each clus- 
ter to that cluster mean are calculated. These distances are summed up. Then, into one new cluster those clusters that give the smallest increase in the total amount of distances are combined $[2,3]$.

As a result of the procedures, 2 clusters were created:

- first cluster - 28.6\% (Stavropol Territory, Republic of Dagestan);

- the second cluster - 71.4\% (Republic of Ingushetia, Chechen Republic, Kabardino-Balkarian Republic, Karachai-Cherkes Republic, North Ossetia);

The best results in the first cluster on the state of infrastructure and the economy of the tourism industry were shown by the Stavropol Territory and the Republic of Dagestan. The second cluster contains the rest of the regions of the North Caucasus Federal District (Ingushetia, Chechen Republic, Kabardino-Balkarian Republic, Karachai-Cherkes Republic, North Ossetia-Alania), which have similar socio-economic and infrastructural resources.

The majority of balneological resources $(58 \%)$ of the recreational region of the Caucasian Mineral Waters are concentrated in the area of the Stavropol Territory, in the Karachay-Cherkess Republic - 33\%, in the KabardinoBalkarian Republic $-9 \%$. The combination of natural factors, the geographical proximity of the Stavropol Territory with a historically developed tourist infrastructure has a significant impact on the tourism industry of the KabardinoBalkarian Republic, Karachai-Cherkes Republic.

Results. The influence of tourist flow on the indicators of the "Socio-economic environment" block is ambiguous: the average positive feedback with "GRP per capita", which does not have a noticeable effect on the "Average per capita income of the population per month". This may be due to the insignificant share of the tourism industry in the sectoral gross value added of about $3 \%$. At the same time, the indicator "Unemployment rate" $(-0.59-0.58)$ shows an inverse feedback with changes in the number of tourists, ie reduction in tourist flow contributes to the growth of unemployment. All this will affect the economic situation of the single-industry towns - resorts of the Caucasian Mineral Waters group (Stavropol segment).

The amount of tourist traffic, accomodation capacity and services of sanatorium-resort institutions have a strong negative feedback to indicator "Share of investments in fixed assets from the budget", which characterizes the significant role of the budget in the development of infrastructure. As most of the health resort institutions are in departmental, trade union and municipal property.

When the tourist flow changes, there remains a negative impact on the environment (due to the use of utilities) and safety indicators (there is a likelihood of committing crimes, both by tourists and local residents against them). In connection with the economic crisis, the role of rail and road transport is increasing.

Thus, under scenarios of decreases in tourist flow from $100 \%$ to $50 \%$ and $30 \%$, the dynamics of correlations of the studied indicators shows a non-critical dynamics of weakening the tightness of connection. Probably, there are hidden nonlinear dependencies of the studied indicators. The stress test showed a certain margin of safety for the health resort complex of the Caucasian Mineral Waters region (with a time lag): 30\% of the tourist flow roughly corresponds to the contingent of health resort institutions, i.e. major consumers of medical and recreational services. Government support is needed to maintain the foundation of the recreational industry. Of the 124 sanatoriums in the Stavropol Territory, only $16 \%$ are privately owned. It is necessary to ensure the fulfillment of all the tasks set in the subprogram "Development of the tourist cluster in the North Caucasus Federal District."

Local authorities offer a standard set of support measures that partially cover the conditionally fixed costs: property tax benefits (up to 1\%), land tax benefits, government guarantees for obtaining interest-free loans, and lease payments deferral. It is necessary to further stimulate the demand for Health resort and recreational services through the development of domestic tourism, the provision of preferential vouchers to the population at the expense of social funds, and subsidies for travel to the vacation spot.

\section{ЛИТЕРАТУРА}

1. Андриевская И.К. Стресс-тестирование: обзор методологий // VIII Международная научная конференция. Модернизация экономики и общественное развитие: В 3 кн.Кн.3 М.: Издательский дом ГУ-ВПГЭ, 2007. С.34-43

2. Батуров А.ВОценка конкурентоспособности отдельных территорий регионального туристического ктастера Северного Кавказа //(2065 в перечне ВАК на 30.11.2018)У правление экономическими системами: электронный научный журнал.-Кисловодск: «Д-Медиа», 2019. №3. URL: http://www.uecs.ru

3. Батуров А.В, Кшишневская В.Ф. Сегментирование регионального туристического рынка Северного Кавказа // (1685 в перечне ВАК на 10.11.2017)Современная наука и инновации.- Ставрополь - Пятигорск: Институт сервиса, туризма и дизайна (филиал) СКФУ в г.Пятигорске, 2017. №3(19). С.10-16.

4. Давыденко И.Г. Дефинициальная определенность и типологизация туристских финансовых рисков // Теория и практика общественного развития. 2015. № 22. С.48-51.

5. Гудков А.А., Дедкова Е.Г. Управление рисками на предприятиях отрасли туризма // Управление финансовыми рисками. 2017. No3. С.216-227.

6. Коронакризис-2020: Что будет и что делать? Сценарии развития и меры экономической политики// Либеральная миссия - экспертиза. Выпуск 9. Москва. Апрель, 2020. 47c.

7. Заернюк B.М., Филимонова Н..І. Актуальные направления совершенствования методов оценки устойчивости и надежности туристических организаций // Финансовая аналитика: проблемы и рештения. 2015. №17 (251). С.37-46.

8. Львова М. В., Воскресенская Н. В. Концептуальные основы управления рисками в системе внутреннего контроля хозяйствуюших субъектов. Современные проблемы науки и образования. 2013. № 6. С.501-502. 
9. Морозов М.А., Рубин Ю.Б., Бубнова Г.В. Модели управ.ления предпринимательскими структурами в туризме в условиях риска и неопределенности // Прикладная информатика. 2012. № 6 (42).C. 102-107.

10. Орлова С.ІО. Отчет о результатах контрольного мероприятия «Проверка целевого и результативного использования в 2018 году и истекшем периоде 2019 года средств федерального бюджета, направленных в уставный капитал акционерного общества «Курорты Северного Кавказа», а также реализации задач подпрограммы «Развитие туристического кластера в Северо-Кавказском федеральном округе» государственной программы Российской Федерации «Развитие СевероКавказского федерального округа» на период до 2025 года» Счетная палата Российской Федерации, 2020. 34c.

11. Санаторно-курортная отрасль опасается банкротств // Газета «Коммерсантъ» №57 от 31.03.2020. С.7.

12. Финансово-кредитный энциклопедический словарь / Колл.авторов ; Под общ. ред. А.Г. Грязновой. М.: Финансы и статистика, $2002.1168 \mathrm{c}$.

\section{REFERENCES}

1. Andrievskaya I.K. Stress-testirovanie: obzor metodologij // VIII Mezhdunarodnaya nauchnaya konferenciya. Modernizaciya ekonomiki i obshchestvennoe razvitie: V 3 kn. Kn.3 M.: Izdatel'skij dom GU-VSHE, 2007. S.34-43

2. Baturov A.VOcenka konkurentosposobnosti otdel'nyh territorij regional'nogo turisticheskogo klastera Severnogo Kavkaza // (2065 v perechne VAK na 30.11.2018) Upravlenie ekonomicheskimi sistemami: elektronnyj nauchnyj zhurnal. Kislovodsk: «D-Media», 2019. №3. URL: http://www.uecs.ru

3. Baturov A.V., Kshishnevskaya V.F. Segmentirovanie regional'nogo turisticheskogo rynka Severnogo Kavkaza // (1685 v perechne VAK na 10.11.2017) Sovremennaya nauka i innovacii. Stavropol' - Pyatigorsk: Institut servisa, turizma i dizajna (filial) SKFU v g.Pyatigorske, 2017. №3(19). S.10-16.

4. Davydenko I.G. Definicial'naya opredelennost' i tipologizaciya turistskih finansovyh riskov // Teoriya i praktika obshchestvennogo razvitiya. 2015. № 22. S.48-51.

5. Gudkov A.A., Dedkova E.G. Upravlenie riskami na predpriyatiyah otrasli turizma // Upravlenie finansovymi riskami. 2017. No3. S.216-227.

6. Koronakrizis-2020: Chto budet i chto delat'? Scenarii razvitiya i mery ekonomicheskoj politiki// Liberal'naya missiya ekspertiza. Vypusk 9. Moskva. Aprel', 2020. 47s.

7. Zaernyuk V.M., Filimonova N.N. Aktual'nye napravleniya sovershenstvovaniya metodov ocenki ustojchivosti i nadezhnosti turisticheskih organizacij // Finansovaya analitika: problemy i resheniya. 2015. №17 (251). S.37-46.

8. L'vova M.V., Voskresenskaya N.V. Konceptual'nye osnovy upravleniya riskami v sisteme vnutrennego kontrolya hozyajstvuyushchih sub"ektov. Sovremennye problemy nauki i obrazovaniya. 2013. № 6. S.501-502.

9. Morozov M.A., Rubin YU.B., Bubnova G.V. Modeli upravleniya predprinimatel'skimi strukturami v turizme v usloviyah riska i neopredelennosti // Prikladnaya informatika. 2012. № 6 (42).S. 102-107.

10. Orlova S.YU. Otchet o rezul'tatah kontrol'nogo meropriyatiya «Proverka celevogo i rezul'tativnogo ispol'zovaniya v 2018 godu i istekshem periode 2019 goda sredstv federal'nogo byudzheta, napravlennyh v ustavnyj kapital akcionernogo obshchestva «Kurorty Severnogo Kavkaza», a takzhe realizacii zadach podprogrammy «Razvitie turisticheskogo klastera v Severo-Kavkazskom federal'nom okruge» gosudarstvennoj programmy Rossijskoj Federacii «Razvitie Severo-Kavkazskogo federal'nogo okruga» na period do 2025 goda» Schetnaya palata Rossijskoj Federacii, 2020. 34s.

11. Sanatorno-kurortnaya otrasl' opasaetsya bankrotstv // Gazeta «Kommersant"» №57 ot 31.03.2020. S.7. tika, 2002. $1168 \mathrm{~s}$.

12. Finansovo-kreditnyj enciklopedicheskij slovar' / Koll.avtorov ; Pod obshch. red. A.G. Gryaznovoj. M.: Finansy i statis-

\section{OБ ABTOPAX | ABOUT AUTHORS}

Батуров Андрей Вадимович, канд. фармац. наук, доцент кафедры «Технологии продуктов питания и товароведения», Институт сервиса, туризма и дизайна (филиал) СКФУ в г. Пятигорске, тел.: 89054970310, E-mail: andreybaturow@yandex.ru.

Baturov Andrey Vadimovich, Ph.D. of Pharm. Sc., Associate Professor, Associate Professor of Department of «Technology of food and merchandizing», Institute of Service, Tourism and Design (branch) NCFU in Pyatigorsk, phone: 89054970310,E-mail: andreybaturow@yandex.ru.

Кшишневская Валентина Федоровна, канд. экономич. наук, доцент, главный бухгалтер, Институт сервиса, туризма и дизайна (филиал) СКФУ в г. Пятигорске, тел. : 8(8793)337769, E-mail: Buh-pf@pfil.ncstu.ru.

Kshishnevskaya Valentina Fedorovna, Ph.D. of Economics, Associate Professor, Chief Accountant, Institute of Service, Tourism and Design (branch) NCFU in Pyatigorsk, phone: 8(8793)337769,

E-mail: Buh-pf@pfil.ncstu.ru. 